\title{
(1) \\ The COVID-19 epoch: Interdisciplinary research towards a new just and sustainable ethic
}

\author{
Zenaida Lauda-Rodriguez \\ Beatriz Milz \\ Igor Matheus Santana-Chaves \\ Pedro Henrique Campello Torres \\ Pedro Roberto Jacobi
}

(D) ${ }^{I}$ Ambiente $\mathcal{B}$ Sociedade Editorial Executive Secretariat. PhD from the Environment Science Graduate Program (PROCAM), University of São Paulo.

São Paulo/SP - Brasil

II Ambiente $\mathcal{E}$ Sociedade Editorial Executive Secretariat. PhD candidate at the Environment Science Graduate Program (PROCAM), University of São Paulo São Paulo/SP - Brasil

(D) III Ambiente $\mathcal{E}$ Sociedade Editorial Executive Secretariat. PhD candidate at the Graduate Program in Planning and Territorial Management (PGT), Federal University of $A B C$

Santo André/SP - Brasil

IV Ambiente $\mathcal{B}$ Sociedade Associated Editor. Postdoc fellow at the Institute of Environment and Energy (IEE) University of São Paulo

São Paulo/SP - Brasil

IV Ambiente $\mathcal{B}$ Sociedade Editor -in-chief. Senior Full Professor the Environment Science Graduate Program (PROCAM), University of São Paulo

São Paulo/SP - Brasil
São Paulo. Vol. 23, 2020

Editorial

Debating ideas

DOI: http://dx.doi.org/10.1590/1809-4422asoceditorialvu2020L3ED 
On March 11, 2020, the World Health Organization (WHO) declared the COVID-19 pandemic. Despite potentially reaching everyone in the four corners of the planet, not everyone is affected in the same way (MAROKO; NASH; PAVILONIS, 2020; OUTRIGHT, 2020; TORRES; LINKE, 2020). Studies already indicate an uneven distribution among the affected groups, with a focus on most vulnerable populations. The beginning of the pandemic has generated a series of tensions and conflicts in academic activities. Whether due to the difficulties imposed by forced distance learning that several institutions had to adhere to without any pedagogical preparation. Or by the challenges that researchers (men, women, or non-binaries), especially with children, have been experiencing due to the accumulation of daily activities, by the pressure to produce knowledge in a period of exception (MINELLO, 2020; CORBERA et al., 2020).

Aware of this, the editorial board of Ambiente \& Sociedade journal released on March 24 a message to the community informing the option of not interrupting the work during the period, but alerting for a decrease in the production pace, possible delays and the impossibility of corroborating with a particular current "academic normality". Academic productivity should not come first, the note said. But assistance to communities, students, relatives, and colleagues. Therefore, it is about seeking an academic culture of care, as proposed by Corbera et al. (2020). Towards a transformation that could transform academic practices related to just sustainability, solidary, and sorority ethics by the crisis end.

But the illusions of a world "post-COVID" fairer, less consumerist, and supportive quickly vanished through the air. Exceptions, as a form of resistance, are spaces of hope, authentic "invented spaces of action" (MIRAFTAB, 2016), in which insurgent collective actions of reaction and mobilization operate in the vacuum of inoperative public action. As the expansion of the virus left the spheres of the upper and middle classes (in fact, it was the mobility capacity of these classes that facilitated the spread of the virus around the world) and in the face of the erratic posture of government leaders for containment and confrontation from the crisis generated by the arrival of the virus, several initiatives were spreading in several regions of Brazil so that the more fragile populations and with less capacity of response, could face the pandemic.

Examples like the Landless Rural Workers Movement (MST) that has been providing food, medical care and other support to thousands of Brazilians across the country during the pandemic; the organization in the Paraisópolis favela, in São Paulo, under the leadership of the Paraisópolis Women's Association; initiatives such as the Mothers of the Favela, linked to CUFA (Central Única de Favelas) which consists of the delivery of $\mathrm{R} \$ 120.00$ Mother Vouchers in around 500 Brazilian favelas; welcoming the vulnerable population of transsexuals, transvestites and transgender people to Casa Nem, in Rio de Janeiro, during the pandemic; and collection of donations by diverse groups and collectives such as the Articulation of Indigenous Peoples in Brazil - APIB, the União de Núcleos de Educação Popular para Negras/os e Classe Trabalhadora - UNEafro, Base-WarmisConvergence of Cultures Team that works with population migrant, among many other initiatives, account for the capacity for organization and cooperation, as well as the sense of solidarity and empathy among the groups most affected by the crisis. 
However, these crucial initiatives face an enormous challenge ahead: the continuity of a crisis that shows no signs of a close solution and, on the contrary, signals horizons of vast economic and social crises, submerging humanity in uncertainty. The main problem in this scenario, and which goes against the illusion of a "post-COVID" world, is that there will be no "post-COVID". Although, in the following months, thanks to the tireless work of thousands of scientists around the world, we finally develop treatments for the disease. Or get the much-desired vaccine against coronavirus, what we will be looking at will be the continuity and resurgence of a system of social organization that excludes and degrades the most impoverished and weakened social groups.

As has already been developed in several critical articles, the pandemic's systemic effects can be addressed from different perspectives of analysis; however, all are connected between them. Since the economic approach, the natural and rapid spread of the virus through physical approximation and human mobility has severely impacted the neoliberal capitalist model, strengthened in recent decades by globalization. After the first cases in China, we have seen how the measures of restraint and social isolation, applied to prevent the spread of the virus, quickly paralyzed the second largest economy in the world, causing a cascade effect on several production chains, from the local to global.

However, even if this economic slowdown is global, its effects have not affected everyone in the same way. The lowest strata of the productive economy and the most excluded groups in the system are the most affected. In an economic model that is based on overproduction and exacerbation of consumption for its maintenance and growth. Measures such as people's immobility have affected the continuity of production and especially that of consumption, affecting both those who have capacity but cannot continue consuming and (and mainly) those who depend on the consumption of others for income generation. It is where the injustices in the system become most visible. For the most impoverished groups, whose income was already very low or only subsistence, compliance with the primary protection measure against contagion by COVID-19, social isolation, has simply been impractical. Without sufficient economic resources, thousands of people around the world risk their health and their families in an attempt to guarantee daily food, which becomes even more precarious in a scenario of economic paralysis. It has allowed for greater visibility of the weaknesses of an economic model that was already in crisis and that today, in times of pandemic, only accentuates its effects by deepening the pre-existing social and economic inequalities.

This scenario of workforce paralysis in the service sector (mainly) in different regions of the world exposed the contagion risk of thousands of people due to the need for economic support. As well as the collapse of health systems for the care of those has led to the deceptive confrontation between the maintenance of the economy and the right to health. Defenders of neoliberal economics have begun to revive old theories based on the so-called "Social Darwinism". Which preaches a sort of "natural" selection in the productive world. Only those best able to maintain the capitalist economic system can overcome the financial crisis generated by the pandemic. Measures and efforts by nations to keep their populations isolated for the preservation of life and their health, harm the 
economy, which may lead to a more significant "post-COVID" crisis.

That is why, according to Acselrad (2020), neoliberal rhetoric has nothing to say about pandemics, climate change, or deaths from air pollution. On the contrary, it sells technological optimism, accentuates xenophobism, in addition to exposing the most vulnerable to the undesirable effects of diseases brought on by the pandemic. It reveals pre-existing conditions of environmental inequalities, such as lack of access to water, sanitation, housing, quality air, among others.

In this view, the good or interest to be protected is the production and generation of wealth. The thousands of human lives that we have lost, and continue to lose, have value only as producers of wealth. This logic shows the explicit dehumanization of an economic model that disregards structural failures that put millions of people in the asymmetrical competition. Determined not only by the current capacity of respondents to the crisis (possibility of isolation and access to a health system) but also due to historical inequality and segregation. A clear example of this is precisely the need to mobilize the most impoverished and excluded groups in society to face the pandemic. Poorest, black community and traditional populations, LGBTQIA+, migrants, the homeless, among others, had to organize collaboratively to achieve, as far as possible, meet social isolation.

However, it must be clear: there is no economy without people! It is the people who make the economy and not the other way around! This is what brings down the fallacy of the contrast between economics and health. The economy must be an instrument for maintaining people's lives in dignity and not the other way around. All of this should lead us to strengthen several studies that question the well-known and perverse arrangements of the capitalist economy. And, at the same time, propose economic alternatives with greater social justice, with special emphasis on combating inequality, and in the context of climate change, which should further tension segregation and inequity across the planet.

From government actions to combat the pandemic, except for the Prime Minister of Belgium, criticized for the way she has managed to cope with COVID-19 in her country, it is necessary to recognize the active role in countries governed by women, with better results, as in the case of Taiwan's leader Tsai Ing-wen, Angela Merkel in Germany, or New Zealand, Prime Minister Jacinda Ardern. The same can be said in San Francisco, USA, led by Mayor London Breed, with a low number of cases and deaths. Crisis management draws attention, especially compared to another significant city in the State of California, Los Angeles, where the numbers are incredibly high ${ }^{1}$.

It is also essential to reflect on decolonial, south-south learning. Like Paraguay, Uruguay, and Argentina, and countries in Southeast Asia, South American countries are good examples that should be observed to reflect on the new urban research agenda and the lessons of crisis management. There is a considerable contrast between the numbers Paraguay, Uruguay, and Argentina concerning Brazil, which is on its way to becoming the world epicenter of the pandemic. Result of the sum of several factors, among them: ignor- 
ing the recommendations made by scientists and international organizations such as the World Health Organization (WHO), lack of transparency of data related to COVID-19, continuous institutional changes, such as the cases of resignations of ministers of health and obstacles to the articulation between the spheres of government.

In manifest contradiction to the constitutional principle of the Dignity of the human person, which involves the protection of human beings in different dimensions that guarantee their adequate development, in Brazil, the pandemic has transcended issues related to health. It has come to be seen as an opportunity for the approval of measures that attempt to protect and preserve the environment. Thus, in the understanding of the current Minister of Environment, Ricardo Salles, the media's attention directed to the development of the pandemic should be used to, in his own words, "pass the cattle," referring to the country's environmental legislation. These questions show the government's erratic policy, especially that of the Executive Branch, led by the President of the Republic, in tackling the pandemic. The mandate's constant attacks against the WHO recommend measures to combat the virus and precaution in the use of medicines that still do not present consistent scientific evidence on their effectiveness. Added to the social and economic pressures that narrow the possibility of confinement of thousands and, due to the complexity of coping with a disease whose studies are still in progress, have created an environment of skepticism and misinformation that constitutes a real challenge for science producers and communicators.

In this sense, the Ambiente \& Sociedade journal joins the efforts of academic production focused on the debate on the impact of COVID-19 in the national territory and presents this section Debating ideas with articles that address the theme in its most diverse dimensions, regions, and areas of knowledge. From an interdisciplinary perspective, with contributions from experts in areas such as history, anthropology, medicine, public health, sociology, territorial planning, biology, among others, this Debating ideas brings together 12 articles that were prioritized in peer review analyses to achieve their prompt publication. A regional and gender diversity was sought, in which $33 \%$ of the articles are signed by women, as the first author. Among all authors and co-authors, the number is $50 \%$.

Our concern for the equal composition of authors (s) in the production of this Debating ideas also responds to reflections within our editorial team about the impacts of the pandemic on academic production, set out above. Between 2017 and 2019, the journal average number of new submissions was around 19 manuscripts per month. Since the beginning of the pandemic, the number of original manuscript submissions to Ambiente \& Sociedade journal has increased, as shown in Figure 1. The month of May 2020 is, until then, the month where the most considerable growth was observed, with 40 submissions, which corresponds to an increase of $110 \%$ concerning the average. However, this significant increase could be hiding a disparity in scientific production. 
Figure 1: Graph of the number of submissions to Ambiente $\&$ Sociedade journal, from January to May 2020

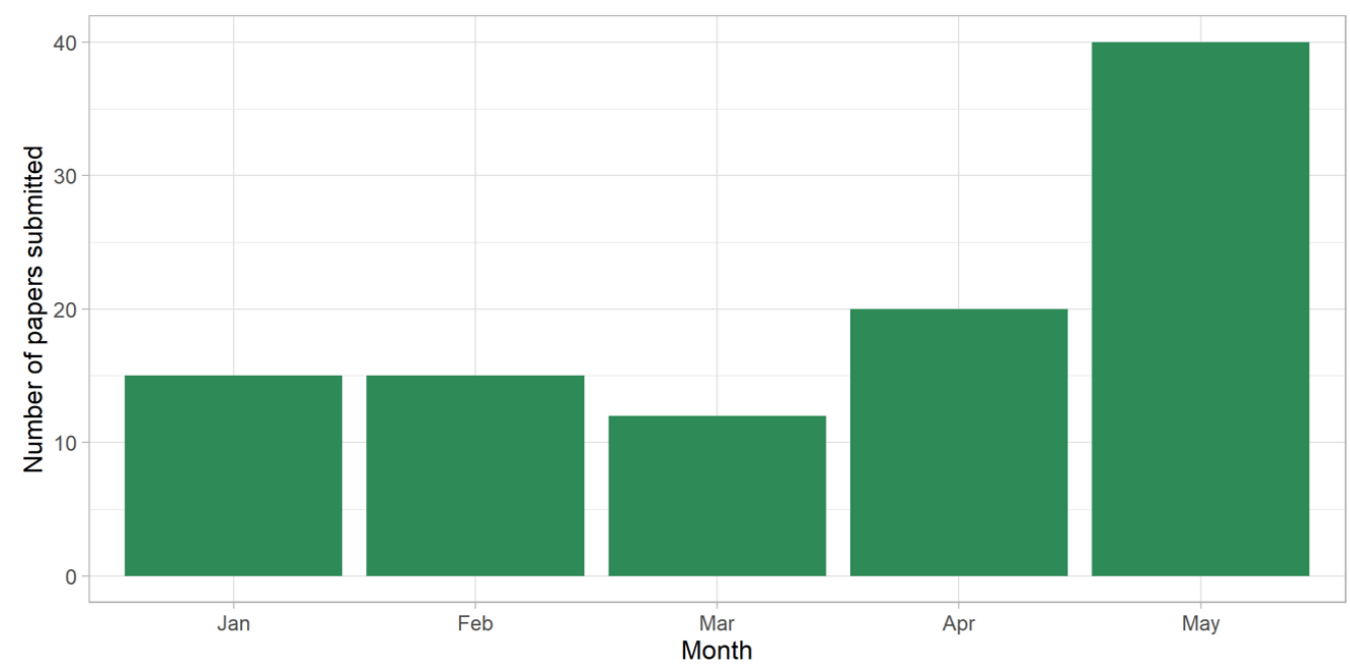

Source: Data obtained in the ScholarOne Manuscripts system, on June 8, 2020. Prepared by the team, using $\mathrm{R}$, and the dplyr and ggplot2 packages.

A preliminary study on academic production during the coronavirus pandemic, using preprint repositories, points out that the rate of increase in submissions as a first author for men is higher than for women (VINCENT-LAMARRE; SUGIMOTO; LARIVIÈRE, 2020). Other news points to similar concerns, highlighting and discussing how pandemics affect the productivity of female researchers (FLARENTY, 2020; SAÉZ, 2020).

These preliminary studies stimulated this discussion in the Editorial team of Ambiente \& Sociedade. The manuscript submission system used by the journal, ScholarOne Manuscripts, does not provide information on the gender of the authors, which makes it challenging to analyze the data of submissions received in this journal, considering the gender cut. Therefore, we intend to subsequently seek ways to analyze these data referring to the period before and during the COVID-19 pandemic and to present the results shortly. We believe that evidence in this sense can contribute to reducing possible situations of inequality in academic production, seeking to strengthen this production from different perspectives and interpretations that lead to achieving one of the main objectives of science, which is: to improve people's quality of life.

We conclude these reflections on the systemic impacts of COVID-19 by raising awareness about the moment in which humanity finds itself. We are facing a problem that explains the weaknesses of a development system that for centuries has been based on the exploitation and oppression of the lives and bodies of historically segregated groups, as well as the exhaustion of resources on a limited planet, overlapping the objective generation profit over people's dignity. It should not continue. The desired normality 
of a "post-COVID" responds, in fact, to the continuity of an unequal society that needs subordinate bodies, worldviews, ideas, and other possibilities of different forms of social interaction, more just and inclusive reproduction and development.

For us, who work with interdisciplinarity, environmental sciences, and dialogue with related sciences, the questions regarding the over-exploitation and pressure of the current development system on nature become more relevant and alert us to possible catastrophic scenarios. The potential emergence of a pandemic due to processes of zoonoses (transmission of a disease capable of being naturally transmitted between animals and humans) warns of the dangerous expansion of human activities within the limits of nature. And that is just the tip of the iceberg. As long as we continue with processes and activities that put pressure on natural systems and do not allow their proper regeneration, new epidemiological outbreaks are latent. This is exacerbated in a climate change scenario, another major factor, also capable of generating systemic crises, which reminds us that nature does not depend on us, human beings, but we do depend on quality. The crisis caused by the coronavirus faces us with the society's fragility in their interaction with nature and calls us to reflect on how to face these challenges better.

Our aim with this editorial is to highlight the urgent need for interdisciplinary dialogue but based on a new sustainable and fair ethics that allows all people to live together in dignity and with all living beings in balance. The articles, from the most diverse perspectives and areas of knowledge, contribute to the reflections mentioned above. They actively bring the notion of Environmental Justice to the center of the research agenda. As well as the imperative needs to work with the issues of inequality and vulnerability. The role of the State also appears as crucial in the articles presented, as well as the necessary - and rarely present - collaborative governance among federated entities. The theme of the Amazon, indigenous peoples, and the impact of COVID in the region is also included, as well as the spread of the virus in the city's peripheries. Several articles that make up this special debating ideas also address the issue of climate emergence and its correlations with the coronavirus, or even with the possibility of new pandemics.

In the article "Beyond the virus: There cannot be a pandemic without the State", Rodrigo Toniol writes about the importance of the State as the originator of the pandemic. The author starts with the understanding that the notion of pandemic presupposes a genealogy - the result of a historical process and specific political configurations, related to the consolidation of the modern State. As for Toniol, the emergence of the notion of a pandemic must be reflected based on the relationship between the State and socially unequal effects generated by inequality phenomena. The author concludes by suggesting the approximation of the notion of environmental justice as an essential aspect to understand this process.

Zoraide Souza Pessoa, Rylanneive Leonardo Pontes Teixeira, and Maria do Livramento Miranda Clementino, in the article "Interfaces between Vulnerabilities, Governance, Innovation and Capacity of Response to COVID-19 in Brazilian Northeast", discuss how the Northeast region of Brazil has been building response capacity in an innovative and articulated way to the challenges of the pandemic in their territories. The authors 
conclude that in the Brazilian northeast these responses are being conducted in an articulated way considering interfaces between social vulnerability, governance and innovation.

Carla Galvão Pereira and Rafael de Aguiar Arantes analyzed the intergovernmental relationship between the Government of the State of Bahia and the Municipality of Salvador and the measures put in place by them to confront COVID-19 in the article "Fighting COVID-19 in Salvador: cooperation and conflict in intergovernmental relationship". The authors concluded that, despite being led by politicians from groups and parties that are historically antagonistic, the governments of the State of Bahia and the city of Salvador have been adjusting actions and cooperating among themselves to implement policies to face the health crisis.

Deisy de Freitas Lima Ventura, Gabriela Marques di Giulio and Danielle Hanna Rached, in the article "Lessons from the COVID-19 pandemic: sustainability is an indispensable condition of Global Health Security", critically analyze the concept and evolution of Global Health Security agenda, arguing that there can be no security in matters of public health when sustainability in its multiple dimensions is not taken into account.

Considering that the COVID-19 pandemic is devastating indigenous communities, in the article "Fighting the invisible anaconda amidst a war of conquest: notes of a genocide", author Felipe Milanez argues that the structural racism that led to almost 200 deaths of indigenous people in the first months of the pandemic must be seen not as a result of irresponsible acts of omission, but as acts of genocide.

Fabio de Castro, Gabriela Russo Lopes, and Eduardo Sonnewend Brondizio, in the article "The Brazilian Amazon in Times of COVID-19: From crisis to transformation?", aims to turn the attention to practices by local communities and indigenous groups in the Brazilian Amazon as a starting point to rethink our present and reshape our future. Conclude that new paths are needed to overcome the 'old normal' of the Amazon region, marked by the destructive extraction of resources and social inequalities, and to change to a 'new normal', based on transformations for a more sustainable and equitable society.

In the article "Global analysis of the infection by COVID-19", Marcos Silveira Buckeridge presented his research based on data available in public databases. He examined the infection levels of 56 countries, and found patterns that revealed a striking difference between Asian and European countries, with much higher infection levels in the European countries. The author concluded that the pandemic's evolution could be better explained as a multifactorial phenomenon and a better view from a systemic point of view.

In "COVID-19: Local/regional inequalities and impacts over critical healthcare infrastructure in Brazil", Wilson Cabral de Sousa Júnior, Demerval Aparecido Gonçalves and Dafne Brito Cruz address local / regional issues on critical health infrastructure to deal with COVID-19, based on geospatial analysis and compartmental modeling (SEIR), using as a study area the Macrometrópole Paulista (SPMM) and the Metropolitan Region of Vale do Paraíba / North Coast of SP (RMVPLN). The authors conclude that for future resilience, it is essential to address inequalities in terms of health infrastructure available for public and private access. 
Researchers Luciana R. F. C. Travassos, Renata M. P. Moreira, and Rayssa Saidel Cortez, present their article called "The virus, the disease and the inequality", and analyzes the data of cases and deaths reported on COVID-19 in the city of São Paulo (SP - Brazil), allowing to relate the evolution of the pandemic with inequalities already present in the country. São Paulo urban space and with the different social conditions that exist to adhere to isolation.

Carlos Machado de Freitas, Isadora Vida de Mefano e Silva, and Natalia da Cunha Cidade, in the article entitled "COVID-19 as a global disaster: Challenges to risk governance and social vulnerability in Brazil", discuss the current pandemic as a Global Disaster that can evolve into a Complex Emergency involving the potential for a $\mathrm{Hu}$ manitarian Crisis in many countries, including Brazil. In the article, the authors present threats that undermine the capacity for risk governance and widen and intensify social inequalities, making Brazil the new epicenter of the global disaster by COVID-19.

In the article "Pandemics, existential and non-existential risks to humanity", the author Luiz Marques discusses how the pandemic started an era of structural economic stagnation, crossing the threshold at which the so-called "ecosystem services" of the planet begin to become "Ecosystem services." On the other hand, Marques concludes, the current pandemic offers a chance for a significant civilizational turn, probably the last opportunity before environmental imbalances get out of the control of societies.

The author's Nelson Gouveia and Claudio Kanai, in the article entitled "Pandemics, cities and Public Health", discuss how public health and urban planning, which for the authors were strongly connected, separated, and focused mainly on sanitation policies. Public health and urban planning must, therefore, reconnect, as new and old health threats brought about by urbanization and highlighted by the current pandemic have emphasized the close relationship between health and the urban environment. When preparing for the post-pandemic, the authors conclude that health must return to the center of decisions related to urban life.

To conclude, it is essential to mention that this volume of the journal will present and initiate a new 'design' for the presentation of published articles. Continuing our commitment, started in mid-1997, to contribute to scientific development through the lens of interdisciplinary knowledge about the Ambiente \& Sociedade in an accessible, modern, and diverse way. After several studies and a horizontal process of collective construction between the Executive Secretariat, the Editor-in-Chief and Deputy Editors, Ambiente \& Sociedade now appears with a new layout for its articles, updated, attractive and organized.

Following the structure and format of other publications in the scientific field, we assume a new arrangement of elements: the first page with the summary, information of the authors and volume, number of DOI and keywords; new fonts were adopted for the titles and text; hyperlink in $\mathrm{ORCiD}$; acknowledgments precede references; a contact session for the principal author and other co-authors; inclusion of the dates of receipt and acceptance of articles, so that the average time of the editorial process can be monitored; a "how to quote" item and, finally, the last pages with the abstract/resume in other languages - Portuguese, Spanish and English. All of these elements were designed to make reading 
on screen easier, since, since 2011, we have become a digital and online publication.

It is also important to highlight that in our commitment to research and science and, mainly, to our authors, readers and collaborators, we will seek to index our journal in more knowledge networks (digital databases of journals), as well as reducing the time of the publication process, without losing any stage that compromises the quality of our publications, so much appreciated by the members of the journal.

We take this opportunity to thank the entire editorial staff of Ambiente \& Sociedade journal, and especially the Executive Secretariat, in the form of Anna Luiza Abreu, Rafael Monteiro and Juliana Delgado, and the Deputy Editors, who promptly accepted the challenge, amid the pandemic and the difficulties that it imposes on us, to prioritize this edition as a scientific contribution from the environmental area in an interdisciplinary perspective to the debate on the effects of COVID-19 on society. In sum, to contribute to a critical reflection of the time we live in, we wish that this edition illuminates the scientific and political debate in the country, in addition to stimulating research and future paths that address the theme and its challenges.

We wish everyone a good reading! 


\section{References}

ACSELRAD, H. A microbiologia cega do capitalismo. Boletim ANPOCS, vol. 37, 2020. Avaible from: http:/www.anpocs.com/index.php/ciencias-sociais/destaques/2351-boletim-n-37-cientistas-sociais-e-o-coronavirus acesso: maio 2020.

CORBERA, E.; ANGUELOVSKI, I.; HONEY-ROSÉS, J.; RUIZ-MALLÉN, I. Academia in the Time of COVID-19: Towards an Ethics of Care. Planning Theory and Practice. 2020.

FLAHERTY, C. No Room of One's Own: Early journal submission data suggest COVID-19 is tanking women's research productivity. 21 de abril de 2020. Avaible from: < https://www.insidehighered.com/news/2020/04/21/early-journal-submission-data-suggest-covid-19-tanking-womens-research-productivity>. Access on: 12 June 2020.

HOPKINS, J. COVID-19 Dashboard by the Center for Systems Science and Engineering (CSSE) at Johns Hopkins University (JHU). Baltimore: Johns Hopkins University, 2020. Avaible from: < https://coronavirus.jhu.edu/map.html>. Access on: May 2020.

MINELLO, A. The pandemic and the female academic. 17 de abril de 2020. Avaible from: < https://www.nature.com/articles/d41586-020-01135-9>. Access on: May 2020.

MAROKO, A.; NASH, D.; PAVILONIS, B. "Covid-19 and Inequity: A comparative spatial analysis of New York City and Chicago hot spots" (2020). CUNY Academic Works. Avaible from: $<$ https://academicworks.cuny.edu/sph_pubs/258>. Access on: May 2020.

MIRAFTAB, F. Insurgência, planejamento e a perspectiva de um urbanismo humano. Revista Brasileira de Estudos Urbanos e Regionais (RBEUR), 18, no. 3, p. 363-377. 2016.

SAÉZ, C. "Estoy fallando como investigadora y madre": la COVID-19 amplía la brecha de género en ciencia. 08 de junho de 2020. Avaible from: < https://www.agenciasinc.es/Reportajes/Estoy-fallando-como-investigadora-y-madre-la-COVID-19-amplia-la-brecha-de-genero-en-ciencia ?fbclid=IwAR00pLbfgAmdfL7APYIFpT9xHNHFhTE14uUs7b9BPV_EVnJ7Q0f-oKgDyR8>. Access on: 12 June 2020.

TORRES, P., LINKE, C. Covid-19 e a política urbana: a densidade não é a vilã. Le Monde Diplomatique, 2020. Avaible from: https://diplomatique.org.br/covid-19-e-a-politica-urbana-a-densidade-nao-e-a-vila/ Access on: 12 June 2020.

VINCENT-LAMARRE, P.; SUGIMOTO, C. R.; LARIVIÈRE, V. The decline of women's research production during the coronavirus pandemic. Nature Index. 19 de maio de 2020. Avaible from: <http://natureindex.com/news-blog/decline-women-scientist-research-publishing-production-coronavirus-pandemic $>$. Access on: 12 June 2020.

OUTRIGHT INTERNATIONAL. 2020. Vulnerability Amplified: The Impact of the COVID-19 Pandemic on LGBTIQ People. Avaible from: < https:/outrightinternational.org/sites/default/files/COVIDsReportDesign_FINAL_LR_0.pdf > Access on: May 2020. 
Zenaida Luisa Lauda-Rodriguez

2020;23:e00003

$\square$ zeni.lauda.rodriguez@gmail.com

ORCiD: http://orcid.org/0000-0003-2432-0255

\section{Beatriz Milz}

$\square$ beatriz.milz@usp.br

ORCiD: https://orcid.org/0000-0002-3064-4486

\section{Igor Matheus Santana-Chaves}

$\square$ igor.chaves@ufabc.edu.br

ORCiD: https://orcid.org/0000-0003-3833-9301

\section{Pedro Henrique Campello Torres}

$\square$ pedrotorres@usp.br

ORCiD: https://orcid.org/0000-0002-0468-4329

\section{Pedro Roberto Jacobi}

$\square$ prjacobi@gmail.com

ORCiD: http://orcid.org/0000-0001-6143-3019

How to cite: LAUDA-RODRIGUEZ, Z. et al. Editorial - The COVID-19 epoch: Interdisciplinary research towards a new just and sustainable ethic. Ambiente $\mathbb{E}$ Sociedade. São Paulo, v. 23, p. 1-12, 2020. 